\title{
Storytelling and its potential in the development of tourist destinations in the post-pandemic age
}

\author{
Lyudmila Semenova ${ }^{1}$, Tatiana Klimova $^{2}$, and Irina Bogomazova ${ }^{2}$ \\ ${ }^{1}$ Immanuel Kant Baltic Federal University, st. Gorky, 32, 236041 Kaliningrad, Russia \\ ${ }^{2}$ Belgorod State National Research University, st. Pobedy, 85, 308015 Belgorod, Russia
}

\begin{abstract}
Information obtained from any source is forgotten after three days. The exception is the one that is of particular importance and is broadcast through stories. The ongoing transformation of the needs of tourists is reflected in the diversification of the tourist offer. In this regard, storytelling has received particular relevance and development. Storytelling technologies are the process of communicating information as a result of the use of stories and legends. The article analyzes the state and development prospects of the region as an attractive tourist destination, suggests a model for promoting a regional tourist destination based on storytelling. The development and comprehensive implementation of projects, taking into account the interests of all participants, will provide an opportunity to promote and develop the territory as an attractive tourist destination, which is of paramount importance in modern socio-economic conditions.
\end{abstract}

\section{Introduction}

The COVID-19 coronavirus pandemic and the travel restrictions are changing the development potential of the tourism industry, both in Russia and around the world. The results of 2020 testify to the deplorable state of the tourism sector and, as a result, its finding in extreme conditions. According to the Border Service of the Federal Security Service of the Russian Federation, Russian citizens made 71\% fewer trips compared to 2019, namely 14 million trips to foreign countries, and more than half of the trips fell on the "pre-quarantine" first quarter of 2020 - almost $54 \%$.

The new reality determined the transformation of tourists' approaches to choosing a destination - the main factor is not the price of the tour and sympathy, the primary factor is the opportunity to travel to a country that is open for Russian tourists, as well as the existence of quarantine requirements for foreigners.

In this regard, special attention should be paid to domestic and inbound tourism. So, according to analysts' forecasts, major tour operators plan to develop exclusive tours as well as cultural, educational and beach tourism. According to representatives of travel companies, the priority geographic destinations within Russia are the Black Sea coast, St. Petersburg and the Baltic coast, Moscow and the Golden Ring, the Urals and the Baikal region.

The growing popularity of domestic tourism is confirmed by Yandex and Sberbank research. According to the study "Where Russians Rest" (Yandex, 2019), which characterizes the main trends in the domestic tourism market in Russia and is based on the results of travelrelated queries, the most popular type of tourism in Russia is domestic. According to the 
number of requests for specific cities and resorts, the list is as follows - Sochi, Moscow, Anapa, St. Petersburg, Yaroslavl and Vladimir.

Sberbank's research ("What regions earn on domestic tourism: preliminary results of 2018") analyzed the customers' bank cards spendings and reflected on the main areas of the domestic tourism market, its volume (almost 900 billion rubles). Among the important trends, it is worth noting the growth in the volume of interregional travel around the country with an annual growth rate of $30 \%$. 30 regions of Russia receive net income from domestic tourism: traditionally, the Krasnodar region and St. Petersburg are leading by a large margin, Moscow and the region spend as much on tourism as they get from it.

In general, the trend remains unchanged - despite all the difficulties and problems, certain territories enjoy the development of tourism. In this regard, it is worth considering the capacities of depressive tourist destinations and their potential based on various technologies, including storytelling.

The widespread digitalization and use of the Internet has led to an increase in the role and influence of the latter, which has defined it as an excellent space for telling impressive stories and expressing the most daring ideas. Current Internet users are constantly experimenting with the modes of presenting their material, combining at first glance incompatible formats. A special area of interest is storytelling as the art of telling stories and writing readable texts. The role and purpose of storytelling is to engage readers in the storyline and then retain them. Sophisticated and quality storytelling is not only a combination of consistent methodology and technique, but an art that is characterized by creativity, vision, skills and practice.

The tourism industry has sufficient resources to activate stories due to the combination of the present and the past, and in combination with the main character - the tourist - there is a synergistic effect in the form of the initiation of new myths, legends, the popularization of historical heroes and events. The implementation of such projects allows to provide communication that awakens curiosity, fosters a culture of relationships, thereby allowing the return of the tourist, ensuring his loyalty and a sense of belonging.

Currently, almost every region of the world and Russia has at its disposal a rich and centuries-old history, unique ethnic communities, a complex cognitive system of myths, fairy tales and legends. The interest of recent years, generated by this area, determines a steady demand among tourists. It should be stated that for the modern tourist, it is the images generated by tourist destinations and resource bases that are fundamental in the process of satisfying motivation. The expectation of the amazing, mysterious and unknown determines the development of tourist destinations. Vast spaces, large territories and specific places make it possible to use legends and myths, and this, in turn, is the basis for the development of tourism $[1 ; 2]$.

The use of myths, legends and fairy tales in the system of promoting tourist destinations is an important component in the formation of tourist motives and travel. Tourist legends in most cases are more attractive and interesting than real facts, which determines their widespread use and inexhaustible potential.

\section{Materials and methods}

Storytelling as a promotion technology is a marketing tool based on presenting a story with the necessary message for the target audience. Translated from English "storytelling" is the creating of stories that can be broadcast into the media space through myths, legends, fairy tales and stories, books, theatrical performances, public appearances.

The founder of this is David Armstrong, when in 1922 his theory of "MBSA - Managing by Storying Around" was based on the principles of implementing the management process from the standpoint of a non-standard and creative approach, describing life situations, analyzing examples and stories [3]. 
The practical application of storytelling technologies in tourism is efficient for both organizations and regions. The resource for shaping the tourism experience is found in tourism legends that have become an integral part of the industry. In the context of territory branding growth, tourist legends can act as a development factor for the image and brands of tourist centers and territories. For example, "Mikhail Kozhukhov's Travel Club" offers programs of tourist routes, appeal to potential tourists, attracts the main character to the journey - "the soul of the company" (famous musicians, artists and writers), allows you to convey information and deliver the traveling experience in an unusual, interesting context [4].

The implementation of projects based on storytelling, focused on the actualization of the interest of tourists in the regions, is carried out in Nizhny Novgorod ("nnstories"), the Pskov, Kirov, Tver regions, the Republic of Tatarstan.

In recent years, particular attention has been paid to the digital aspects. The federal mobile guide TopTripTipRussia contains practical everyday information about all regions of Russia, answering the most popular tourist questions: how to get, where to stay, what to see and try. However, for many regions there is an obvious shortage of emotionally colored content images, stories, myths and legends written in modern language, tightly connected with reallife objects.

MTS company has launched a free audio tour of the sights of Astrakhan, which is based on the preferences of the townspeople. The initiative was implemented within the framework of the MTS social project "Urban Legends". You can walk the route with a smartphone in an hour, and download it in the izi.TRAVEL and Surprise Me mobile applications [5].

The Belgorod region is a region with rich history and a unique cultural and historical heritage, with a large number of historical and cultural monuments, a set of festivals and holidays. At the same time, it lacks active involvement and application of innovative technologies that would affect the promotion of the region and contribute to bringing the tourism sector to a new level of development.

Analysis of the current state indicates that the information space accumulating tourist legends is most fully represented by the Cultural Region portal, which both tells about the most interesting events taking place in Belgorod and the Belgorod region, and introduces tourist routes $[6 ; 7 ; 8]$.

In general, the information is structured according to the territorial principle (legends of Belgorod, Shebekino, Rakitny, Volokonovka, Grayvoron, Borisovka, Korochi) and is presented in a clear-cut way, for example:

— "Esslinger's Brewery. Haven't you heard of this? Then read this story quickly";

— "The "gates" of the city: how the entrances to old Belgorod were decorated";

— "How Shebekino suddenly turned out to be the sugar capital";

— "The house of the merchant Selivanov is a puzzle: one-storied outside, but not inside!";

— "Friends, have you ever won something really worthy? But the hero of this story, merchant and industrialist Mikhail Barkov has";

— "What does the history of the Round Building hide? Why is it considered a cosmic temple of the sun, and how can it be related to the Order of Masonry?";

- "Rumor has it that the famous Count Sheremetev, whose noble family is closely connected with the history of Borisovka, had his own harem ...".

As for other information channels, it should be noted that the official tourism portal of the Department of Economic Development (http://beltourism31.ru/) is under development and does not contain information on regional tourism opportunities.

Also, residents and guests of the region can be offered individual and group excursions containing elements of storytelling. The Tripster portal offers for booking - "Belgorod history and legends" and "Mystical Belgorod, or in search of an invisible city". 
A large number of legends accompany the history of the region's development ("Witches and Margarita", "Bald Mountain", "Lake of Love", "Horse from the Fog", "House of Horror", "Ghost Tanks"), but in general they do not belong to the category " tourist legends", which undoubtedly reduces the possibility of their promotion outside the region [9].

Modern travelers are more demanding and curious. They want not only to listen to the excursion, to watch what is happening, but also, being on the tour, to participate in some kind of interactive program associated with the information sphere, which allows them to create a unique and most competitive tourist product. The Belgorod region, like Russia as a whole, has all the resources to attract more tourists to its localities, developing not only domestic tourism, but also inbound tourism.

\section{Results and Discussion}

The available tourism potential, based on the regional resource base, can be grouped in the following areas.

1. Natural and archaeological resources that can act as the production of tourist stories and legends:

- nature reserves and protected areas (Belogorye Nature Reserve, Monastyrsky Forest);

- archaeological sites (Krapivenskoe settlement, Dmitrievskoe settlement);

- natural attractions (Pansky oak, long-lived oak in Oak settlement, Korochansky gardens);

- caves (Shmarnenskaya cave, Kholkovsky caves);

- landscapes (Lebedinsky Quarry, Bekaryukovsky Wood, Kamenny Log Ravine, Petrovskie Borki Tract, Bolshie Kulbaki Tract, Kalinov Yar, Vorontsov Territory, Upland Oak Forest "Forest on Vorskla");

- springs (Holy spring Krinitsa, Spring "Clear well").

2. Cultural and historical sites that can promote the reputation of the territory:

— museum-reserves (museum-reserve "Prokhorovskoe field");

- museums (Museum-diorama "Battle of Kursk. Belgorod direction", Belgorod Museum of Folk Culture, Belgorod Museum of History and Local Lore, Belgorod Art Museum);

- Monuments of history, culture and architecture (Kholkovsky Monastery, Barkov's Mill, Yusupovs Palace Complex in Rakitnoye, Merchant Selivanov's House, Smolensk Cathedral, Transfiguration Cathedral, Church of the Holy Martyrs Faith, Hope, Lyubov and Their Mother Sophia, Assumption-Nicholas Cathedral, Round building);

- open-air museums and estates (Park Klyuchi, the Center for Traditional Culture and the Museum of the village of Kupino, the fortress city of Yablonov, the village of Khotmyzhsk, the village of Sukharevo, the estate "Sabynino" (estate of Volkonskikh), the estate "Setnoe" (estate of Alferov), the estate "Uderovka" (estate of the Stankevichs), the estate of A.A. Karamzin-Kleinmichel, the estate "Arkhangelskaya" with a park of the 19th century, the village of Arkhangelskoye);

- monuments (Monument to Vladimir the Great, a monument to the Army General I.R. Apanasenko, a monument to tank-driver A.I. Popov, a monument to Major General M.P. Lebed, a memorial sign in honor of the Army General N.F. Vatutin, a sign of honor "Military glory");

— places of residence of famous people (M.S.Schepkin, N.V. Stankevich, S.A. Degtyarev, G.Ya. Lomakin, V.G. Shukhov.).

3. Socio-cultural objects and events:

- festivals (BelMelFest, Skies of Belogorye, Foma's Fried eggs, Russian Porridge, Grillfest, International Music Festival "Borislav Strulev and His Friends”, Malanya, Yusupov 
Collections, Patterned Round Dance);

— street art objects (graffiti - the city has about 20 murals dedicated to the anniversaries of Victory in the Great Patriotic War, poet Vladimir Mayakovsky, cosmonaut Yuri Gagarin, athlete Fedor Emelianenko);

— sculptural compositions - "Volleyball players", "Students", "Pushkin and Natalie", "Locomotives of perestroika", "Monument to an honest traffic cop", etc.

Tourist legends act as a special resource of the region, as well as a component of the tourism brand and storytelling technology. In any case, tourist legend as a resource or technology is an effective tool for promoting tourist destinations.

The use of storytelling technology in the process of promoting the Belgorod region as a tourist destination and the popularization of tourist resources should be carried out in the following areas:

— information on tourist portals;

- development of a regional information site;

- posts on social networks.

The introduction of elements of streettelling and tourist legend will expand the geography and variety of tourist routes, involve various market actors in the tourism system for the development and development of priority tourism areas (tourists, government bodies, local population, economic entities), based on the fixed model and its components:

— resources, including natural and archaeological resources, cultural and historical sites, socio-cultural sites and events;

- tourist legend and storytelling;

— subjects of tourism - tourists, public authorities, local population, economic entities.

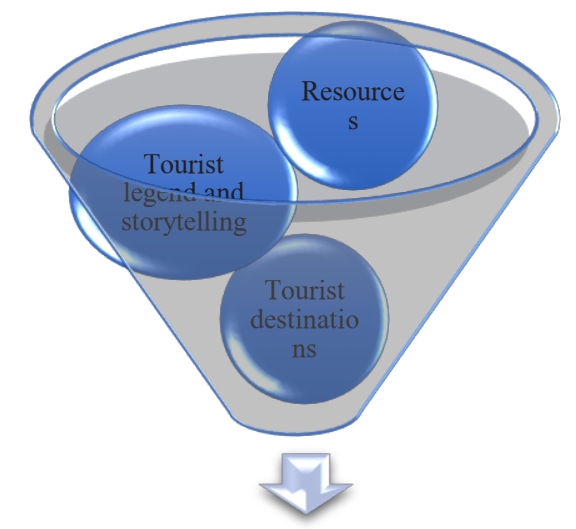

Promotion and development of tourist destinations

Fig. 1. A model of promoting a regional tourist destination based on storytelling.

Storytelling technologies gives advantages to a regional tourist product, and also positively influences the behavior of potential tourists, motivating them to travel, which determines the attractiveness and competitiveness of the territory. The activities in these areas will ensure the comprehensive development of the territory as an attractive tourist destination. 


\section{Conclusions}

The process of information promotion based on tourist legend and storytelling of a regional tourist destination can have a positive impact on the attractiveness of tourism in the region and serve as a driving force for increasing the level of service for tourists.

In order to diversify the tourist offer, it is necessary to actively promote the tourist destination, including with the involvement of all subjects. Special attention is paid to modern technologies, which, ultimately, not only provide communication with consumers, but also make it possible to analyze the quality of service and the promotion process in order to increase the competitiveness of a regional tourist destination.

\section{References}

1. O. E. Afanaiev, A. V. Afanasieva, Current issues of service and tourism (2017)

2. P. S. Shirinkin, Tourist legend: regional aspects (Perm region): textbook, 260 (2014)

3. D. G. Armstrong, Managing by Storying Around: A New Method of Leadership (1992)

4. M. Kozhukhov's travel club, http://mktravelclub.ru/

5. MTS will help tourists get to know Astrakhan with a mobile audio guide, https://arbuztoday.ru

6. Contact sculptures of Belgorod. Route through the contact monuments of the city, https://bel.cultreg.ru

7. Legends of the Belgorod land: who, where and why. Cultural region, https://bel.cultreg.ru

8. Graffiti route. Traveling around Belgorod in search of the most interesting murals, https://bel.cultreg.ru

9. Mysticism of Belogorie, https://fishki.net/ 